\title{
INSTITUTIONAL INVESTORS OWNERSHIP AND FIRM VALUE: EVIDENCE FROM MALAYSIA
}

\author{
Nurul Azlin Azmi ${ }^{1 *}$, Fazrul Hanim Abd Sata ${ }^{1}$, Norhidayah Abdullah ${ }^{1}$, \\ Noor Hidayah Ab Aziz ${ }^{1}$ and Ida Suriya Ismail ${ }^{2}$ \\ ${ }^{1}$ Senior Lecturer, Faculty of Accountancy, \\ Universiti Teknologi MARA, Segamat, Johor, Malaysia. \\ ${ }^{2}$ Senior Lecturer, Faculty of Accountancy, \\ Universiti Teknologi MARA, Puncak Alam, Selangor, Malaysia.
}

\begin{abstract}
Institutional investors play a significant role as an external watchdog to promote good governance to uphold firm value. The existence of institutional investors as shareholders is able to reduce the agency problem and the costs that arise from shareholder-manager relationship. This study aimed to examine the influence of institutional investors' shareholdings and firm value among public listed firms in Malaysia. Specifically, it is argued that only pressure-insensitive institutional investors play an active monitoring role to increase a firm's value, while pressure-sensitive investors, do not. This study employed 595 public listed firms from the main market in Bursa Malaysia for the period 2013 to 2017 (2795 firm-year observations). The results show that the pressure-sensitive and pressure-insensitive investors are positively significant to a firm's value. These findings revealed that institutional investors in Malaysia play a significant role in increasing a firm's value. This study will have a significant contribution to firms and the academic literature which states that all types of institutional investors in Malaysia are effectively monitoring their roles as an external corporate governance watchdog. The existence of these investors will be able to promote better governance and increase a firm's value.
\end{abstract}

Keywords: institutional ownership, pressure-insensitive and pressure sensitive institutional investors, firm's value

\section{$\underline{\text { ARTICLE INFO }}$}

\section{Article History:}

Received: 2 July 2020

Accepted: 15 March 2021

Published: 30 April 2021

* Corresponding Author: Nurul Azlin Azmi. E-mail: nuru1516@uitm.edu.my 


\section{INTRODUCTION}

The presence of institutional investors as a major player in the global financial market is due to the substantial shareholding in the investee firms. Prior studies have documented that institutional investors have a significant influence over their investee firms because they are able to encourage good governance, influence appropriate behaviours, and increase firm value (Jennings, 2005; Sakawa \& Watanabel, 2020; Wang, 2019). The introduction of the Malaysian Code of Institutional Investors (MCII) in 2014, helped ensure corporate governance quality and shareholder's return by strengthening the accountability of institutional investors to their own members as well as other investors. Despite the rising importance of institutional ownership, institutional investors' effectiveness is being questioned and has drawn the attention of academic researchers and practitioners, especially the pressure-sensitive investors.

Prior studies have classified institutional investors into two main groups, according to their business relationships with a firm, which are pressure-insensitive and pressure-sensitive investors. Pressure-insensitive investors such as large institutional shareholders as listed by MSWG (for example, EPF, LTAT, PNB, LTH, and SOCSO), pension fund, and stateowned investors, refers to investors who have no business relationship with a firm. Meanwhile, pressure-sensitive investors refers to investors that have business relationship such as insurance, banking, financial intermediaries, and other investors. Prior studies debate that pressure-sensitive investors have fewer incentives to invest in monitoring and they tend to act as 'traders' rather than 'owners' as compared to pressure-insensitive investors (Lin, 2016). It became serious when Njah and Trabelsi (2019) found that different types of institutional investors ownership have significant effects on the quality of financial reporting and firm value. Consequently, the effectiveness of institutional investors as the external governance watchdog is being debated among researchers.

This study intended to examine whether the existence of institutional investors and different groups of investors have a significant effect on a firm's value. This study was motivated by two main considerations. First, due to the mixed and inconclusive findings found in prior literature between institutional investors and a firm's value. Second, while there is ample 
evidence to support this association, it is important to establish whether the introduction of Malaysian Code of Institutional Investors (MCII) is able to improve institutional investors' monitoring as an active external governance watchdog. This paper attempts to provide some understanding and support for this issue.

Our study contributes to the extended literature in several ways. This study fills the gap by examining the association between institutional investors' shareholding and a firm's value after the introduction of MCII. In addition, this study examined the association of different types of institutional investors by taking into account the uniqueness of the Malaysian business environment that is dominated by large institutional investors. This paper is organized as follows: the next section discusses the institutional background of the study, followed by a discussion of the literature and hypothesis development, research methodology, and the findings of the study. In the last section, we will explain the conclusion, limitations and suggestions for future studies.

\section{INSTITUTIONAL BACKGROUND}

In 2011, the Securities Commission of Malaysia issued a recommendation on the role of institutional investors in corporate governance. Recommendation 2.3.1 of the Malaysian Code of Corporate Governance (MCCG) recommends that institutional investors effectively exercise their ownership rights to ensure the proper functioning of the board of directors, promoting transparency, and information disclosure to the market. In 2014, the Malaysian Code for institutional investors was introduced to promote leadership in governance and responsible ownership by institutional investors. The formulation of this industry-led Code is a recommendation made under the Corporate Governance Blueprint 2011 and was spearheaded by the Malaysian Shareholders Watchdog Group (MSWG) and Securities Commission. Indeed, this is a significant landmark in consolidating the role of institutional investors in Malaysia, especially in mitigating agency problems in firms.

Institutional investors are bound by the Malaysian Code of Institutional Investors (MCII) that sets out the broad principles regarding the stewardship 
and monitoring between institutional investors and investee firms. Demsetz and Lehn (1985) defined institutional investors as "investors who held shares in a management capacity (e.g., investment advisory agreements or trust agreements), the party for whom they managed the shares are identified as the holder with investment power". In the Malaysian context, the Securities Commission has defined institutional investors as asset owners and asset managers with equity holdings in corporations listed on Bursa Malaysia. Institutional investors are responsible for managing the collected funds on behalf of their beneficiaries through an investment (Minority Shareholders Watchdog Group \& Securities Commission Malaysia, 2014).

In addition, the MCCG 2007 clearly states that institutional investors have a role in corporate governance in Part 3, paragraph 4.80 which states that "given the weight of their votes, the way in which institutional shareholders use their power to influence the standard of corporate governance is of fundamental importance...". Therefore, institutional investors are accountable to ensure that the firms are exercising good corporate governance. On the other hand, Principle 2 of the Malaysian Code of Institutional Investors (MCII 2014) reiterates that institutional investors should actively monitor their investee firms, quality of corporate reporting and uphold high firm value.

The Institutional Investors Council Malaysia (IICM 2018) listed out prominent public institutional investors in Malaysia which comprises of the Employees Provident Fund (EPF), Lembaga Tabung Angkatan Tentera (LTAT), Permodalan Nasional Berhad (PNB), Lembaga Tabung Haji (LTH), Social Security Organization of Malaysia (SOCSO), Malaysian Association of Asset Managers, Malaysian Takaful Association, and Private Pension Administrator Malaysia. The largest government-controlled institutional investors with $70 \%$ of total institutional shareholdings are Permodalan Nasional Berhad (PNB), Lembaga Tabung Haji (LTH), Employees Provident Fund (EPF), Lembaga Tabung Angkatan Tentera (LTAT), and Social Security Organization of Malaysia (SOCSO). Institutional investors act as a unified entity. They can be categorised based on the type of organisation, such as pension funds, mutual funds, investment bankers, and insurance firms (Abd-Mutalib et al., 2016).

In Malaysia, institutional investors from the ten largest firms in Bursa Malaysia own 51\% of shares (Saleh et al., 2010). Based on the 
2015 statistics, EPF which is known for being Malaysia's largest pension fund, holds approximately USD190 billion (Towers Watson, 2016). This is supported by Abd-Mutalib et al. (2016) who documented that the largest share ownership in the Malaysian market is in unit trusts and mutual fund institutions.

However, the degree of ownership engagement by institutional investors will identify the level of participation in a firm's decision played by investors (Celik \& Isaksson, 2013). This study argues that there are seven features that influence institutional investors participation in firms. The features include the purpose of the institution whether it is profitoriented or non-profit oriented, liability structure, investment strategy, portfolio and fee structure, the presence of political and social objectives, and the regulations involved in the institutional activities. The link between the degree of ownership engagement and those characteristics can lead to different categories of investors' engagement in firms. Therefore, different categories of investors' engagement in business was the motivation for this study.

\section{LITERATURE REVIEW AND HYPOTHESIS DEVELOPMENT}

Most studies in ownership structure and firm value use the Agency Theory as the underlying basis of research propositions due to the distinct ownership and control between managers and shareholders. Conflict of interest in ownership structures happens when the major shareholders' interests undermine the interests of minority shareholders (Arosa et al., 2010). The appearance of institutional investors plays an effective role in reducing agency problems and costs between stakeholders and firms (Koh, 2003). Through the monitoring process, institutional shareholders are able to reduce agency problems by protecting minority shareholders' interests (Chazi et al., 2011), promoting good governance (Abdul Jalil \& Abdul Rahman, 2010) and increasing a firm's value.

Malaysian firms have a unique characteristic as a majority of public listed firms are held by institutional investors (Abd-Mutalib et al., 2016). Institutional investors are backed by experience, technical, and financial 
resources to influence the financial reporting process and thus affect firm value. Institutional investors effectively play their role particularly by applying pressure to managers to enhance sustainable firm performance in a stakeholder-oriented system (Sakawa \& Watanabel, 2020).

Various studies were as conducted by prior researchers on the effect of institutional investors and firm value. Jennings (2005) found that an institutional ownership that performs monitoring activities on firms can boost firm quality and valuation. Supported with the roles of institutional investors as an external governance watchdog in providing greater monitoring intensity to boost a firm's earnings (Wang, 2019). In addition, Sakawa and Watanabel (2020) found that institutional investors dispense their monitoring roles effectively in firms which catalysed the performance of Japanese firms.

However, the impact of institutional ownership on a firm's performance also shows no agreed relationship. Duggal and Millar (1999) also found no significant impact between institutional ownership on a firm's value. On the other hand, Bhattacharya and Graham (2007) found that institutional investors with probable investment and business links with firms have negative effects on a firm's value. Al-Najjar (2015) argued that there is no significant relationship between institutional ownership and firm performance for Jordanian listed firms. Recent study by Musallam et al. (2019) found a negative association between institutional investor ownership and firm performance in Indonesian firms. Their results ran in the opposite direction of prior studies due to the weak corporate governance and legal enforcement in the Indonesian capital market. Study by Musallam et al. (2019) aligned with Tsouknidis (2019) which also found a negative relationship between institutional investors and a firm's value in listed shipping firms.

Mixed findings were found among institutional investors ownership and firm value. This study believes that the benefit played by the institutional ownership outweigh the negative effects of those association on firm value. Effective monitoring roles of institutional investors can increase corporate governance quality and firm value (Abdul Jalil \& Abdul Rahman, 2010; Sakawa \& Watanabel, 2020; Tee, 2019; Wang, 2019). Moreover, institutional investors in Malaysia are governed by regulations stipulated under the 
Malaysian Code of Institutional Investors (MCII 2014). Therefore, the following hypothesis is proposed:

H1: Institutional investors are associated with a higher firm value.

Further examination divided institutional ownership into distinct categories, and it was found that only pressure-insensitive investors have a positive effect on firm value while pressure-sensitive investors have a negative effect on firm performance (De-la-Hoz \& Pombo, 2016; Jennings, 2005). Furthermore, Abdul Wahab et al. (2008) found only pressure- insensitive investors played effective monitoring roles than other types of institutional investors. Abd-Mutalib et al. (2013) classified institutional investors into a long-term and short-term investment horizon and found that long-term institutional investors were positively significant with sustainability reporting. These evidence reveal that different types of institutional investors is an important factor that may influence firm value.

Other than looking into the type of investment horizon, Aggarwal et al. (2011) looked at portfolio holding of the institutional investor, whether it is local or international i.e., from outside of the United States. They found that foreign institutions from countries with strong shareholders protection show better performance than those from local institutions. This is due to the existence of good corporate governance practices around the world. In line with Lin and $\mathrm{Fu}$ (2017) foreign and institutional ownership has a positive effect on a firm's value in China. Mukhopadhyay and Chakraborty (2017) also found that foreign institutional investors have a positive influence on firm value among Indian listed firms. However, the finding by Tee (2017) revealed that local institutional investors were able to improve share prices as compared to foreign investors in Malaysian firms. Contradicting findings were found due to different regulations as Malaysia is considered to have better regulatory systems and effective guidance to institutional investors which is governed by the MCII.

Mixed findings were found between types of institutional investors ownership and firm value. Based on the above argument, this study believes that pressure-insensitive investors play better monitoring roles than pressuresensitive investors because the former are immune to business changes (Abdul Wahab et al., 2008; Bamahros \& Wan Hussin, 2015). Therefore, following hypotheses are proposed: 
H2a: Pressure-insensitive institutional investors are associated with a higher firm value.

H2b: Pressure-sensitive institutional investors are associated with a lower firm value.

\section{METHODOLOGY}

This study employed 595 samples from the main market of Bursa Malaysia for five years (2013 to 2017) which contributed to 2,975 firm-year observations. The sample of this study covered all industrial sectors except the banking and financial sectors due to different regulations and high volatility. The data on the institutional shareholdings were extracted from the Orbis Database, while the financial data were extracted from the Eikon Datastream. Table 1 shows the sample selection procedures for this study:

Table 1: Sample Selection Procedures

\begin{tabular}{lc}
\hline & Firms \\
\hline Population & 804 \\
(-) BAFIA & $(54)$ \\
(-) Insufficient data & $(125)$ \\
(-) Outlier & $(30)$ \\
\hline Final sample & $\mathbf{5 9 5}$ \\
\hline
\end{tabular}

Table 2 shows the industry distribution from the final sample. The results showed that the highest tabulation is the Industrial products $(28.74 \%)$, followed by Trading/services (23.87\%), Consumer products $(15.63 \%)$, Properties (14.12\%), while the other industries are below $10 \%$.

Table 2: Industry Distribution

\begin{tabular}{lcc}
\hline \multicolumn{1}{r}{ Industries } & No of Observations & Percentage (\%) \\
\hline Construction & 195 & 6.55 \\
Consumer product & 465 & 15.63 \\
Hotel & 15 & 0.50 \\
Industrial product & 855 & 28.74
\end{tabular}




\begin{tabular}{lcc} 
Mining & 5 & 0.17 \\
Properties & 420 & 14.12 \\
Plantation & 170 & 5.71 \\
IPC & 15 & 0.50 \\
Trading/services & 710 & 23.87 \\
Technology & 125 & 4.20 \\
\hline
\end{tabular}

\section{Measurement Procedures}

\section{Dependent variables}

Firm value is an economic measure that reflects the market value of a business. In accounting, most of the studies on institutional investors and firm value used the Tobin $\mathrm{Q}$, return on assets (ROA), and return on equity (ROE) as proxies for firm performance and value (De-la-Hoz \& Pombo, 2016; Jennings, 2005; Tee, 2018). However, firm performance and value is a subject of contention due to the uncertainties of the Tobin Q, ROA, or $\mathrm{ROE}$ as valid proxies. However, many studies argued that the Tobin Q is considered as the best indicator to measure investment opportunities and a firm's operating performance (Fu et al., 2016). Consistent with prior studies, the dependent variable of this study used the Tobin Q as firm value and was measured by the ratio of market value plus total debt of the firms to total assets.

\section{Independent variables}

This study measured institutional investors ownership by total percentage of combined shareholdings of different groups of investors. This study classified investors into two main groups which is based on institutional investors' business relationships with firms. Following Abdul Wahab et al. (2008), this study classified institutional investors into pressure-insensitive and pressure-sensitive. Pressure-insensitive investors refer to the investors that have no known business relationship with the firm and are immune to the pressure of agreeing with management decisions. Meanwhile, pressuresensitive investors refer to investors who have a business relationship with the firm and as this group of investors are afraid of losing their business, they will succumb to management decisions and abide by it. 
Pressure-insensitive investors are classified into two group of investors which are INSTOWN and INSENSITIVE. INSTOWN is the group of top institutional investors defined under MSWG including EPF, LTAT, PNB, LTH, and SOCSO, while INSENSITIVE refers to the group of investors under the pension fund and state-owned investors. Furthermore, pressuresensitive investors are classified into two groups of investors which are SENSITIVE and INDETERMINATE. SENSITIVE refers to the group of investors such as insurance, banking, and financial intermediaries, while INDETERMINATE refers to the group of investors that do not fall into either of the first three categories.

\section{Control variables}

This study controlled financial characteristics such as firm size, leverage, liquidity and auditor. This study measured firm size using the natural logarithm of total assets as prior studies found that firm size significantly influenced ownership structures and firm performance (Arosa et al., 2010). The firm leverage (LEV) is measured by ratio of total liability to total assets as these financial characteristics may influence ownership and the corporate financial structure (Abdul Jalil \& Abdul Rahman, 2010). Firm liquidity is measured by current ratio of the current assets to current liabilities because firms with high liquidity have significant effect on firm performance. Moreover, this study also controlled the types of auditors (AUDITOR) because firms audited by the Big Four firms are valued higher by the capital market (Asante-Darko et al., 2018). In this study, the types of auditors were assigned with 1 if the firm was audited by the Big Four firms and 0 otherwise.

\section{Regression Model}

Empirical research model was designed to examine the relationship between institutional investors ownership and firm value among public listed firms in Malaysia. The dependent variable is the Tobin Q, while the independent variable is institutional investors ownership. This study also controlled firm size, leverage, liquidity, and auditors as those variables significantly affect the tested variables. The following regression model were used on the hypothesis: 


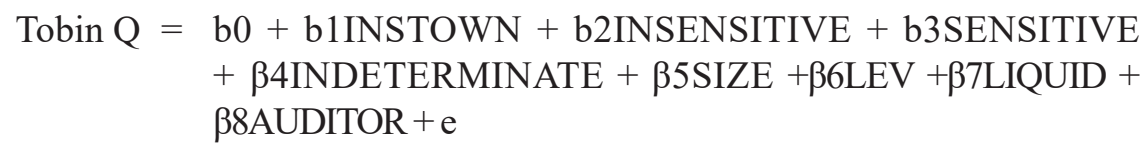

Where;

\begin{tabular}{|c|c|c|}
\hline INSTOWN & $=$ & $\begin{array}{l}\text { Percentage of the combined shareholdings } \\
\text { of top five institutional investors defined } \\
\text { by MSWG }\end{array}$ \\
\hline INSENSITIVE & $=$ & $\begin{array}{l}\text { percentage of the combined shareholdings } \\
\text { of the pension fund and state-owned } \\
\text { investors }\end{array}$ \\
\hline SENSITIVE & $=$ & $\begin{array}{l}\text { percentage of the combined shareholdings } \\
\text { of the insurance, banking, and financial } \\
\text { intermediaries }\end{array}$ \\
\hline INDETERMINATE & $=$ & $\begin{array}{l}\text { percentage of the combined shareholdings } \\
\text { of the others pressure-sensitive investors }\end{array}$ \\
\hline SIZE & $=$ & Natural logarithm total assets \\
\hline LEV & $=$ & a ratio of total liability to total assets \\
\hline LIQUID & $=$ & a ratio of current assets to current liabilities \\
\hline AUDITOR & $=$ & $\begin{array}{l}\text { Dummy variable of } 1 \text { if firms audited by } \\
\text { Big Four and } 0 \text { otherwise }\end{array}$ \\
\hline
\end{tabular}

\section{ANALYSIS AND DISCUSSION}

\section{Descriptive Analysis}

Table 3 Panel A summarizes the descriptive statistics for the variables used in this study. The dependent variable of a firm's value proxied by Tobin Q shows the mean value was 1.1803 with a minimum value of 0.0571 and the maximum value of 15.3554 . The independent variables of institutional investors show that the mean value of top institutional investors (INSTOWN) was $3.20 \%$ with a range of $0 \%$ to $76.41 \%$. This result indicates that there is a firm with no institutional investors as shareholders in the firms; while some of the firms have high share ownership. INSENSITIVE showed a mean value of $0.13 \%$ with a range from $0 \%$ to $45.09 \%$ and indicated 
that the pension fund and state-owned funds held almost half of the shares in the firms. Meanwhile, pressure- sensitive investors that consisted of SENSITIVE and INDETERMINATE showed a mean value of $2.48 \%$ with a range from $0 \%$ to $92.62 \%$ and a mean value of $0.05 \%$ with a range from $0 \%$ to $22.28 \%$ respectively. This result indicates that some firms have a high institutional investors ownership from the insurance, banking sectors, and financial intermediaries.

Control variables showed a mean value for firm size (SIZE) at 13.23 with a range between 0.92 to 18.79 . The firm leverage (LEV) showed a mean value of 0.38 with a range between 0.01 to 2.51. Firm liquidity (LIQUID) showed a mean value is 2.52 with a range between 0.01 to 76.60 . In addition, Panel B showed that $49.51 \%$ of the sample size was audited by the Big Four audit firms; while $50.49 \%$ was audited by the non-Big Four firms.

Table 3: Descriptive Statistics

\begin{tabular}{lcccc}
\hline \multicolumn{5}{c}{ Panel A: Continuous variables } \\
& Mean & Min & Max & Std. Dev \\
\hline Dependent variable & & & & \\
\hline Tobin Q & 1.1803 & 0.0571 & 15.3554 & 1.1298 \\
\hline Independent variables & & & & \\
\hline INSTOWN & 3.2023 & 0 & 76.41 & 8.9957 \\
INSENSITIVE & 0.1326 & 0 & 45.09 & 1.9484 \\
SENSITIVE & 2.4765 & 0 & 92.62 & 9.679 \\
INDETERMINATE & 0.0539 & 0 & 22.28 & 0.7472 \\
\hline Control variables & & & & \\
\hline SIZE & 13.2260 & 9.0159 & 18.7868 & 1.5285 \\
LEV & 0.3819 & 0.0106 & 2.5133 & 0.2127 \\
LIQUID & 2.5174 & 0.0052 & 76.5970 & 5.4901 \\
\hline
\end{tabular}

Note: Tobin $Q$ is measured by market value of equity plus total debt over total assets; INSTOWN is the percentage of the combined shareholdings of the top five institutional investors; INSENSITIVE is the percentage of the combined shareholdings of the pension fund and state-owned investors; SENSITIVE is the percentage of the combined shareholdings of the insurance, banking, and financial intermediaries; INDETERMINATE is the percentage of the combined shareholdings of the others pressure-sensitive investors; SIZE is the natural log of total assets; LEV is ratio of total debt to total equity; and LIQUID is the ratio of current asset to current liabilities. 


\begin{tabular}{lcc}
\hline \multicolumn{3}{c}{ Panel B: Dichotomous variables } \\
\hline & No. of observations & Percentage \\
\hline Big Four & 1473 & 49.51 \\
\hline Non - Big Four & 1502 & 50.49 \\
\hline
\end{tabular}

Note: AUDITOR is an indicator of 1 if the firms audited by Big 4 and 0 otherwise.

\section{Correlation Analysis}

Table 4 shows the Pearson correlation among the variables and the result showed that INSTOWN, SENSITIVE and INDETERMINATE investors are positively correlated and significant at the $1 \%$ level against the Tobin Q. These provide early signals that all types of institutional investors are able to further increase a firm's value; except for INSENSITIVE. Meanwhile, the control variable of firm size (SIZE), firm leverage (LEV), and type of auditor (AUDITOR) showed a positive association; except for firm liquidity (LIQUID) that showed a negative association, and all control variables were significant at the $1 \%$ level on the Tobin $Q$.

With regard to types of institutional investors, only INSENSITIVE investors showed to be positive and significant at the $10 \%$ level on INSTOWN investors. All control variables firm size (SIZE), firm leverage (LEV), firm liquidity (LIQUID), and type of auditor (AUDITOR) were significant at 1\% on INSTOWN. Furthermore, SENSITIVE investors showed to be positive and significant at the $10 \%$ level on INSENSITIVE investors; while firm size (SIZE) and type of auditor (AUDITOR) were positively correlated and significant at $1 \%$ on INSENSITIVE and SENSITIVE investors.

Based on the correlation analysis below, it can be concluded that were no multicollinearity issues since the correlation value for all the variables was below 0.8 (Hair et al., 2010). 
Asia-Pacific Management Accounting Journal, Volume 16 Issue 1

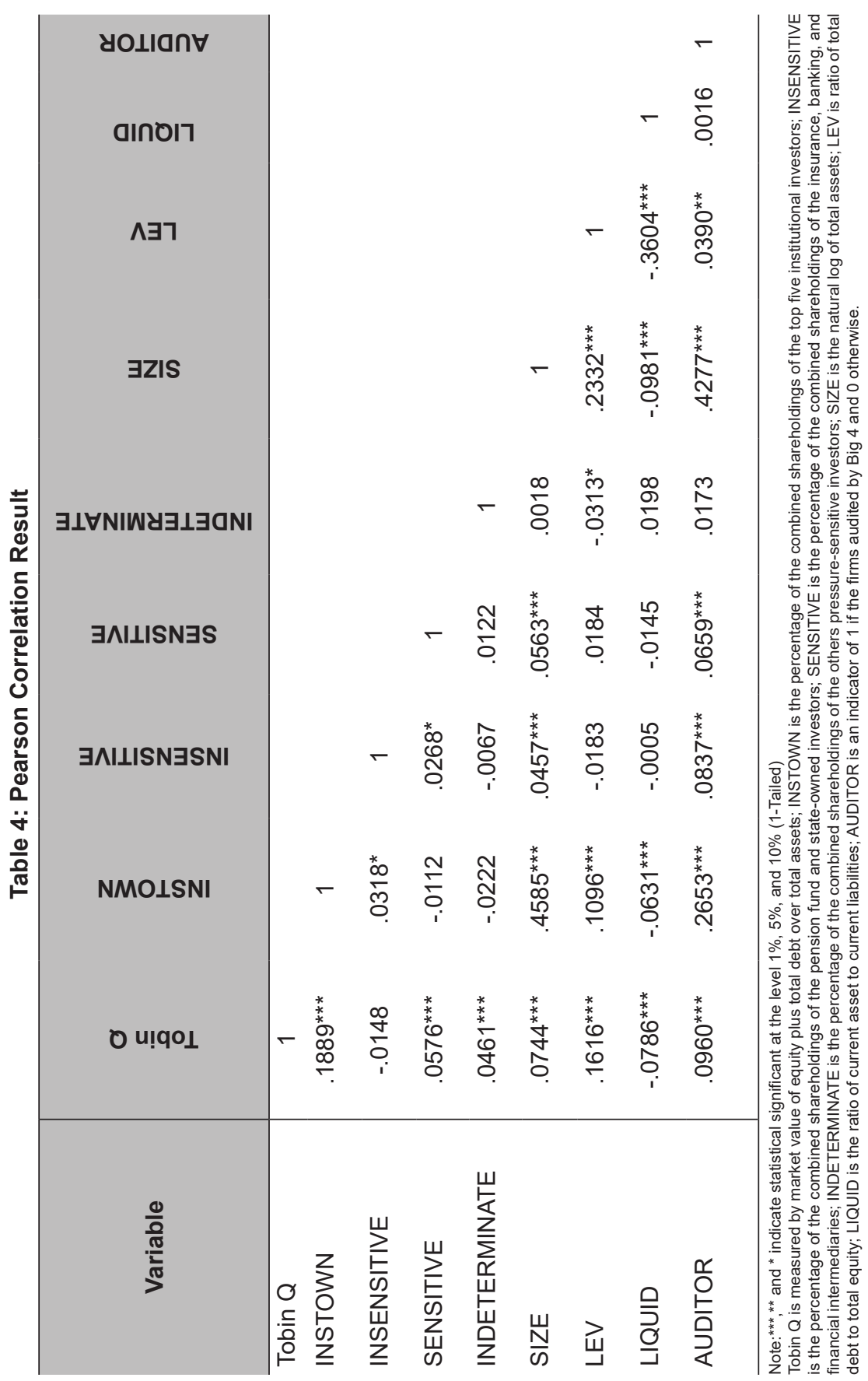




\section{Regression Analysis}

Table 5 shows the multiple regression analysis on a firm's value-Tobin Q. The F-statistic is significant at the $1 \%$ level and indicates the validity of the model estimation, with the adjusted $\mathrm{R} 2$ at $6.66 \%$. The results show that INSTOWN is positive and significant at the $1 \%$ level on Tobin Q. This provides evidence that the existence of the top five institutional investors (EPF, LTAT, LTH, SOCSO and PNB) is able to increase a firm's value. This finding is consistent with a prior study which found that institutional shareholders were able to play the role of an external governance watchdog in providing greater monitoring intensity to boost a firm's earnings (De-laHoz \& Pombo, 2016; Jennings, 2005; Sakawa \& Watanabel, 2020; Wang, 2019).

Meanwhile, SENSITIVE investors showed to be positive and significant at $1 \%$ against Tobin Q and indicated that institutional investors who have business relationships with firms also increased a firm's value. The INDETERMINATE investors showed to be positive and significant at $1 \%$ on Tobin Q and this indicated that the foundation institution investors are able to increase a firm's value. However, this finding contradicts earlier findings which found that pressure-insensitive investors play effective monitoring roles, while pressure-sensitive investors do not (Abd-Mutalib et al., 2013; Abdul Wahab et al., 2008; Tsouknidis, 2019). The inconsistent findings were due to an earlier study being conducted before the introduction of the MCII which spells out the roles and responsibility of institutional investors in Malaysia.

The characteristic of a firm's size (SIZE) showed a negative and was significant at the $1 \%$ level against Tobin Q. It was shown that a larger firm size will have a lower firm value - Tobin Q. Meanwhile, firm leverage (LEV) and type of auditor (AUDITOR) showed a positive association, and both were significant at the $1 \%$ level on Tobin Q. This indicates that firms audited by Big Four audit firms have a high Tobin Q compared to those audited by non-Big Four audit firms. This relationship was expected because firms audited by the Big Four audit firms were able to attract more investors due to the audit firm's reputation and its high financial reporting quality. Therefore, it is able to give confidence to investors to invest, and thus increase a firm's market capitalization (Lee \& Lee, 2013). 
Table 5: Regression Analysis

\begin{tabular}{|c|c|c|}
\hline Variables & Coefficient & T-Statistic \\
\hline Intercept & 0.1289 & 1.33 \\
\hline INSTOWN & 0.0655 & $9.64^{* * *}$ \\
\hline INSENSITIVE & -0.0324 & -1.21 \\
\hline SENSITIVE & 0.0207 & $3.18^{* * *}$ \\
\hline INDETERMINATE & 0.1260 & $3.02^{* * *}$ \\
\hline SIZE & -0.0301 & $-3.85^{\star * *}$ \\
\hline LEV & 0.3840 & $7.70^{* * *}$ \\
\hline LIQUID & -0.0021 & -1.10 \\
\hline AUDITOR & 0.0786 & $3.65^{\star * \star}$ \\
\hline R2 (\%) & 6.91 & \\
\hline Adj.R2 (\%) & 6.66 & \\
\hline F-stat & 27.5157 & \\
\hline P-value & 0.0000 & \\
\hline $\mathrm{N}$ & 2975 & \\
\hline
\end{tabular}

\section{CONCLUSION}

The introduction of the Malaysian Code of Institutional Investors (MCII) in 2014 aimed to improve shareholder's return and promote good governance between institutional investors and public listed firms in Malaysia. The introduction of MCII gave the drive to this study to examine the influence of types of institutional investors ownership and firms value among public listed firms in Malaysia. Based on the sample of 595 firms from 2013 - 2017, this study found evidence where a positive association existed between institutional investors ownership and firm value - Tobin Q but depending on the type of institutional investors. This finding aligns with prior studies which also found similar findings on institutional investors and firm value (De-la-Hoz \& Pombo, 2016; Jennings, 2005; Sakawa \& Watanabel, 2020; Wang, 2019). 
This study established that all types of institutional investors ownership are able to increase a firm's value, except for the pension fund and stateowned investors. The reason might be that the pension fund and state-owned investors are classified as passive investors in which they invest resources not for monitoring purposes. These indicates that both pressure- insensitive and pressure-sensitive investors are able to increase the investee firm value. This finding contradicts the earlier finding whereby only active institutional shareholders play an effective role rather than passive institutional investors (Abd-Mutalib et al., 2013; Abdul Wahab et al., 2008; Tsouknidis, 2019). This shows the effectiveness of the implementation of the MCII among Malaysian firms. The introduction of this code is able to boast pressure-insensitive and pressure-sensitive investors monitoring over investee firms. Consequently, it is able to attract more future investors and indirectly increase a firm's value.

This study is not without any limitation because of its reliance on the top 20 institutional investors from the Orbis Databases. Future studies should further explore the top 30 institutional investors based on published annual reports and examine the effect by using other proxies of firm's value such as return on assets, return on equity, or cash holdings. Furthermore, an extension of future research could classify institutional investor shareholdings into local and foreign categories which may provide stronger findings in this field.

\section{REFERENCES}

Abd-Mutalib, H., Muhammad Jamil, C. Z., \& Wan Hussin, W. N. (2016). Understanding the share ownership of institutional investors in Malaysia. Australian Journal of Basic and Applied Sciences, 10(11), 176-184.

Abd-Mutalib, H., Muhammed Jamil, C. Z., \& Wan Hussin, W. N. (2013). Institutional investors types and sustainability reporting: A study on Malaysian listed firms. Terengganu International Finance and Economics Journal, 3(2), 25-39.

Abdul Jalil, A., \& Abdul Rahman, R. (2010). Institutional investors and earnings management: Malaysian evidence. Journal of Financial Reporting and Accounting, 8(2), 110-127. 
Abdul Wahab, E. A., How, J., \& Verhoeven, P. (2008). Corporate governance and institutional investors: Evidence from Malaysia. Asian Academy of Management Journal of Accounting and Finance, 4(2), 67-90.

Aggarwal, R., Erel, I., Ferreira, M., \& Matos, P. (2011). Does governance travel around the world? Evidence from institutional investors. Journal of Financial Economics, 100(2011), 154-181.

Al-Najjar, B. (2015). Does ownership matter in publicly listed tourism firms? Evidence from Jordan. Tourism Management, 49, 87-96.

Arosa, B., Iturralde, T., \& Maseda, A. (2010). Ownership structure and firm performance in non-listed firms: Evidence from Spain. Journal of Family Business Strategy, 1(2), 88-96.

Asante-Darko, D., Adu Bonsu, B., Famiyeh, S., Kwarteng, A., \& Goka, Y. (2018). Governance structures, cash holdings and firm value on the Ghana Stock Exchange. Corporate Governance, 18(4), 671-685.

Bamahros, H. M., \& Wan Hussin, W. N. (2015). Types of institutional investors and earnings management in Malaysia. Advanced Science Letters, 21(6), 2003-2006.

Bhattacharya, P. S., \& Graham, M. (2007). Institutional ownership and firm performance: Evidence from Finland (School Working Paper Accounting/Finance Series 2007 SWP 2007/01). Retrieved from https:// www.academia.edu/12331904/Institutional_Ownership_and_Firm_ Performance_Evidence_from_Finland

Celik, S., \& Isaksson, M. (2013). Institutional investors and ownership engagement. OECD Journal: Financial Market Trends, 2, 93-114.

Chazi, A., Boubakri, N., \& Zanella, F. (2011). Corporate dividend policy in practice: Evidence from an emerging market with a tax-free environment. Pacific Basin Finance Journal, 19(2), 245-259.

De-la-Hoz, M. C., \& Pombo, C. (2016). Institutional investor heterogeneity and firm valuation: Evidence from Latin America. Emerging Markets Review, 26, 197-221. 
Demsetz, H., \& Lehn, K. (1985). The structure of corporate ownership: Causes and consequences. Journal of Political Economy, 93(6), $1155-1177$.

Duggal, R., \& Millar, J. A. (1999). Institutional ownership and firm performance: The case of bidder returns. Journal of Corporate Finance, 5(2), 103-117.

Fu, L., Singhal, R., \& Parkash, M. (2016). Tobin's Q ratio and firm performance. International Research Journal of Applied Finance, $\operatorname{VII}(4), 1-10$.

Hair, J. F., Black, W. C., Babin, B. J., \& Anderson, R. E. (2010). Multivariate data analysis ( $7^{\text {th }}$ ed.). New York: Pearson/Prentice Hall.

Jennings, W. W. (2005). Further evidence on institutional ownership \& corporate value. Advances in Financial Economics, 11, 167-207.

Koh, P. S. (2003). On the association between institutional ownership and aggressive corporate earnings management in Australia. The British Accounting Review, 35(2), 105-128.

Lee, H. L., \& Lee, H. (2013). Do Big 4 audit firms improve the value relevance of earnings and equity? Managerial Auditing Journal, 28(7), 628-646.

Lin, L. (2016). Institutional ownership composition and accounting conservatism. Review of Quantitative Finance and Accounting, 46(2), 359-385.

Lin, Y. R., \& Fu, X. M. (2017). Does institutional ownership influence firm performance? Evidence from China. International Review of Economics \& Finance, 49, 17-57.

Mukhopadhyay, J., \& Chakraborty, I. (2017). Foreign institutional investment, business groups and firm performance: Evidence from India. Research in International Business and Finance, 39, 454-465. 
Musallam, S. R. M., Fauzi, H., \& Nagu, N. (2019). Family, institutional investors ownerships and corporate performance: The case of Indonesia. Social Responsibility Journal, 15(1), 1-10.

Njah, M., \& Trabelsi, R. (2019). Large institutional investors and the pressure to manage earnings surrounding seasoned equity offerings. International Journal of Law and Management, 61(2), 402-420.

Sakawa, H., \& Watanabel, N. (2020). Institutional ownership and firm performance under stakeholder-oriented corporate governance. Sustainability, 12(3), 10-21.

Saleh, M., Zulkifli, N., \& Muhamad, R. (2010). Corporate social responsibility disclosure and its relation on institutional ownership: Evidence from public listed companies in Malaysia. Managerial Auditing Journal, 25(6), 591-613.

Tee, C. M. (2017). Political connections, institutional investors monitoring and stock price synchronicity: Evidence from Malaysian firms. Managerial Finance, 43(11), 1236-1253.

Tee, C. M. (2018). Family firms, political connections and audit fees: Evidence from Malaysian firms. Managerial Auditing Journal, 33(6-7), 613-632.

Tee, C. M. (2019). Institutional investors' investment preference and monitoring: Evidence from Malaysia. Managerial Finance, 45(9), 1327-1346.

Towers Watson, W. (2016). Global Pension Assets Study 2016.

Tsouknidis, D. A. (2019). The effect of institutional ownership on firm performance: The case of U.S.-listed shipping companies. Maritime Policy \& Management, 46(5), 509-528.

Wang, J. (2019). Long horizon institutional investors and the relation between missing quarterly analyst forecasts and CEO turnover. International Journal of Accounting and Information Management, 27(2), 190-223. 